\title{
Refuge
}

Canada's Journal on Refugees

revue canadienne sur les réfugiés

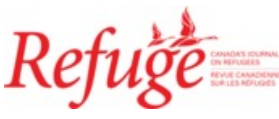

\section{A Double Punishment: The Context of Postsecondary Access for Racialized Precarious Status Migrant Students in Toronto, Canada}

\section{Paloma E. Villegas and Tanya Aberman}

Volume 35, Number 1, 2019

Racialized Refuge

URI: https://id.erudit.org/iderudit/1060676ar

DOI: https://doi.org/10.7202/1060676ar

See table of contents

Publisher(s)

Centre for Refugee Studies, York University

ISSN

0229-5113 (print)

1920-7336 (digital)

Explore this journal

Cite this article

Villegas, P. \& Aberman, T. (2019). A Double Punishment: The Context of Postsecondary Access for Racialized Precarious Status Migrant Students in Toronto, Canada. Refuge, 35(1), 72-82. https://doi.org/10.7202/1060676ar

\section{Article abstract}

This article examines how the immigration and schooling systems in Canada intersect to deny access to migrant youth with precarious status throughout educational trajectories. While there are access policies at the primary and secondary school level, barriers increase in post-secondary education. We argue that such students transitioning to university experience a "double punishment" through racialized exclusion in the education and immigration systems. Our research draws from semi-structured interviews with migrant youth and our experience organizing an access program at York University that targets precarious status students for inclusion. We propose that Canadian universities and policymakers learn from such access programs to increase equitable inclusion at other institutions.
Copyright (c) Refuge: Canada's Journal on Refugees, 2019

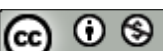

This document is protected by copyright law. Use of the services of Érudit (including reproduction) is subject to its terms and conditions, which can be viewed online.

https://apropos.erudit.org/en/users/policy-on-use/ 


\title{
A Double Punishment: Post-secondary Access for Racialized Migrant Youth with Precarious Status in Toronto, Canada
}

\author{
PALOMA E. VILLEGAS AND TANYA ABERMAN ${ }^{1}$
}

\section{Abstract}

This article examines how the immigration and schooling systems in Canada intersect to deny access to migrant youth with precarious status throughout educational trajectories. While there are access policies at the primary and secondary school level, barriers increase in post-secondary education. We argue that such students transitioning to university experience a "double punishment" through racialized exclusion in the education and immigration systems. Our research draws from semi-structured interviews with migrant youth and our experience organizing an access program at York University that targets precarious status students for inclusion. We propose that Canadian universities and policymakers learn from such access programs to increase equitable inclusion at other institutions.

\section{Résumé}

Cet article examine la manière dont les systèmes d'immigration et d'éducation au Canada bloquent l'accès aux jeunes migrants au statut précaire tout au long de leurs parcours éducatifs. Bien que des politiques d'accès existent aux niveaux primaire et secondaire, les obstacles augmentent au niveau de l'éducation postsecondaire. À partir d'entretiens semi-structurés avec de jeunes migrants et de notre expérience dans l'organisation d'un programme d'accès visant l'inclusion d'étudiants au statut précaire à l'Université York, nous soutenons que les étudiants au statut précaire vivent une «double punition» lors de leur transition à l'université à travers leur exclusion racialisée dans les systèmes déducation et d'immigration. Nous suggérons que les universités canadiennes et les décideurs politiques apprennent des ces programmes d'accès afin d'accroître l'inclusion équitable dans d'autres institutions.

\section{Introduction}

7 he introduction of multiculturalism policies and the end of race-based immigration exclusion in the 1960 s and 1970s produced a "colour-blind" ideology for Canadians, who imagine the country and its systems (including immigration and schooling) as meritocratic and
(C) Paloma E. Villegas and Tanya Aberman, 2019. This open-access work is licensed under a Creative Commons Attribution-NonCommercial 4.0 International Licence, which permits use, reproduction, and distribution in any medium for non-commercial purposes, provided the original authorship is credited and the original publication in Refuge: Canada's Journal on Refugees is cited.
Cette œuvre en libre accès fait l'objet d'une licence Creative Commons Attribution-NonCommercial 4.0 International License, laquelle autorise l'utilisation, la reproduction et la distribution de l'œuvre sur tout support à des fins non commerciales, pourvu que l'auteur ou les auteurs originaux soient mentionnés et que la publication originale dans Refuge: revue canadienne sur les réfugiés soit citée. 
generous. ${ }^{2}$ Yet, while racist exclusion has become more implicit, it continues to underlie many state policies and contribute to the illegalization of migrants. ${ }^{3}$ Options for permanent residence have been shaped, and frequently reshaped, to offer permanent residence to certain migrants only. Those who do not or cannot meet the demands established for this type of inclusion-specific skills, education, wealth, networks, or evidence of persecution legible to the Eurocentric refugee determination system-are left with few options but to seek precarious forms of status, such as temporary work permits, making refugee claims, or remain with no status at all. We use the term precarious immigration status to refer to the legal status of all non-permanent residents, for whom the ability to remain in the country is uncertain and depends on an assemblage of individuals, institutions, and discretionary decision-making. ${ }^{4}$

Schooling for precarious status children has increasingly been seen as a right in North America. In the United States the 1982 Supreme Court decision Plyler v Doe guarantees schooling for any resident child across the country. ${ }^{5}$ In Canada, where education is under provincial jurisdiction, the inclusion of migrant children fluctuates between provinces. In Ontario the provincial Education Act allows students with precarious status to access schooling at the primary and secondary level unless they are deemed to be visitors/tourists. ${ }^{6}$ Yet, despite the inclusionary mandates, schools often remain racialized reception sites, where race-based assumptions and Western-centric curriculum further marginalize students with precarious status. ${ }^{7}$

Students who are able to navigate the school system and successfully graduate face pressure to transition to postsecondary schooling to become "good" members of society; yet they face an uneven terrain of access. In the United States, admission to post-secondary depends on statespecific access, tuition, and financial aid policies. While at least twenty states have policies that permit undocumented students to pursue post-secondary education while paying domestic fees, since the 2016 presidential election, students' sense of belonging and safety on campuses has been affected, despite the declaration of "sanctuary" campuses across the country. ${ }^{8}$ In Canada, access to post-secondary education for precarious status students has not been directly addressed through policy in any province. This significant policy gap invisibilizes precarious status students and the barriers they face to accessing post-secondary education, and produces ad hoc access dependant on particular institutions and their administrators. ${ }^{9}$

This article has two interrelated goals. First, we examine the racist immigration and schooling institutions that produce social exclusion for racialized migrants with precarious status in Canada. Second, we investigate post-secondary access for students with precarious status, highlighting an initiative at York University in Toronto that increased access and inclusion specifically for this population for the first time in Canada. This access program was designed to offer two complementary pathways into the university for students with precarious status: a bridging course for students who felt they needed additional support and preparation to start university, and administrative changes to permit the direct admission of students who did not need bridging. We draw on interviews conducted with students who were part of the first bridging course to explore their experiences of racialized exclusion. We then call for increased access at more post-secondary institutions in Canada.

We argue that the ways race intersects with the immigration system, as well as equitable access to primary and secondary education, leads to a "double punishment" for migrant youth with precarious status. As the result of multilayered racialized exclusion that these students face, they are too frequently barred access to post-secondary education. Our research contributes to continuing debates about the social inclusion of migrants with precarious status, their participation as members of communities despite their legal status, and, heeding the call of Sáenz and Manges Douglas for racializing migration studies, the racialization of migrants with precarious status in Canada. ${ }^{10}$ Finally, we approach this discussion as researchers, and also as activists who have been directly involved in numerous efforts to increase access to education for migrant youth with precarious status. We were also both directly involved in the development and implementation of the access program at York University; therefore we bring our first-hand experience and perspectives to this article.

\section{Legal Status and Race: A Double Punishment for Post-secondary Students}

Our analysis draws on the concept of "double punishment" to think through the experiences of post-secondary students with precarious status. "Double punishment" refers to how migrants with precarious status experience overlapping forms of exclusion and criminalization because of their status. ${ }^{11}$ We use "double punishment" in this article to explore encounters with two systems, immigration and schooling, and how such systems are organized through the interlocking of status and race/racism.

In undertaking this analysis we draw on critical race theory (CRT), which centres race to understand social exclusion and inequality in contemporary society. ${ }^{12}$ Initially emerging from legal scholarship, CRT is widely used in the social sciences and seeks to understand the relationships between power, race, and racialization (the process of identifying/categorizing individuals through the rubric of race). ${ }^{13}$ CRT examines 
how race interlocks with other facets of social exclusion, with an interest in developing transformative practices. ${ }^{14}$ In terms of schooling, CRT examines how students experience rewards and punishments in schooling communities and outside them as the result of their racialization. ${ }^{15}$

In migration/refugee studies, scholars use the language of racialized or racializing "illegality." 16 "Migrant illegality" is a racializing process of identifying individuals as "illegal" due to their specific documents, lack thereof, or assumptions of how migrants look or behave. ${ }^{17}$ It goes beyond a documented/ undocumented binary to examine categories of precarious status including temporary migrant workers, refugee claimants, undocumented/non-status migrants, and other forms of immigration limbo. Garcia refers to racializing "illegality" as "the active and ongoing process of a larger system that conflates race, legal status, nativity, and generation status." ${ }^{18}$ This includes structural disadvantages like deportability (the fear, spectacle, and reality of deportation), ${ }^{19}$ labour market exploitation, and other barriers that migrants with precarious status experience once inside a nation-state.

Given this framework, we identify two areas to frame our analysis: immigration status as a "master status," and the importance of intersectionality. U.S. immigration scholars working on the intersection of status and post-secondary schooling have proposed that being undocumented is a "master status," an axis of marginalization that is more salient than others or eclipses them. ${ }^{20}$ We focus on research in the United States because there is little in other contexts beyond $\mathrm{K}-12$ access. ${ }^{21}$ As a juridical status, precarious immigration status organizes students' eligibility, willingness to apply to university, and the possibility of deportation. ${ }^{22}$ While understanding the centrality of immigration status in migrants' lives (i.e., a master status through which other forms of marginalization are filtered), other scholars argue that an intersectional lens allows scholars to engage in a more nuanced analysis of how forms of oppression are co-constituted. ${ }^{23}$

Immigration status interlocks with social class to affect students' access to financial resources. Students may face responsibilities in contributing to their household income and experience precarious working conditions, affecting their ability to pay tuition, particularly given rising student fees. ${ }^{24}$ These barriers cannot be disentangled from the fact that migrants with precarious status often come from racialized groups that, regardless of legal status, face wage gaps and are overrepresented in precarious employment. ${ }^{25}$ Therefore, racialized students with precarious status face a double punishment when unable to earn enough to support themselves, their families, and their studies.

Social capital is another example of how social class interlocks with immigration status. Social capital refers to "the aggregate of the actual or potential resources which are linked to possession of a durable network of more or less institutionalized relationships of mutual acquaintance or recognition." ${ }^{26}$ Marginalized students, including racialized and working-class groups, tend to have less access to resources and networks than their white and middle-class counterparts. ${ }^{27}$ Undocumented or precarious status students have even less access, including limited information about relevant immigration policies or university application processes. ${ }^{28}$ Their parents may not know how to navigate the system, and teachers might not be knowledgeable or willing to assist. ${ }^{29}$ While students are resilient and, as Enriquez argues, "patch together the resources provided by their social networks," including other undocumented peers, this limitation affects students' educational outcomes. ${ }^{30}$

Research about undocumented migrant university access has focused on Mexican and Latinx ${ }^{31}$ students in the United States, invisibilizing the experiences of other racialized migrants. However, some research has been done with Black and Asian students. Palmer discusses UndocuBlack migrants, who may "pass" as citizens in some contexts, but face heightened police violence, given anti-Black racism and a "connection between privatized prisons and detention centers, and the criminalization of Blackness, as leading from criminal convictions to immigration consequences." ${ }^{32}$ Alternatively, Dao addresses the invisibility of Asian Americans and Pacific Islanders with precarious status, who have to navigate a variety of racial discourses, including those of "model minority," "yellow peril," Islamophobia, and how they connect to illegalization. ${ }^{33}$

These interlocking factors (race, status, and social class) affect the experiences of undocumented/precarious status students when they stop out (take a break from school with the goal of returning) or are pushed out (institutional and systemic practices that lead to student disengagement and "push" students out of schools while framing the issue as an individual or family problem of "dropping out"). ${ }^{34}$ It is estimated that 49 per cent of undocumented migrants in the United States do not finish high school. ${ }^{35}$ The result is that undocumented/precarious status migrants access postsecondary education at lower rates than their citizen, permanent resident, and white counterparts. ${ }^{36}$ Statistics for other countries are unknown.

Students may also be pushed out of post-secondary schooling because they have a limited sense of belonging to schools and their communities. For example, undocumented/precarious status university students may have limited access to campus resources for lack of documentation, limited eligibility, or fear of detection. They also face institutional limitations, particularly when institutional representatives are not knowledgeable of their specific needs. ${ }^{37}$ Another example is campus and community climate. Undocumented/ 
precarious status migrants face what is already a racialized and often explicitly racist campus context. ${ }^{38}$ Clark-Ibáñez, Garcia-Alverdín, and Alva refer to such a climate as "white space," a "hyper hate community climate" that maintains white privilege through "multiple levels of hostility toward immigrants," including acts of violence from hate groups and micro-aggressions from the schooling community. ${ }^{39}$ Students sometimes negotiate negative climates by deemphasizing their immigration status and emphasizing their student identity. ${ }^{40}$ However, institutional barriers and a negative campus climate can lead students to "stop out" (leave school with the intention of returning) at higher rates than other students, again demonstrating a double punishment. ${ }^{41}$

\section{The Canadian Immigration and Schooling Systems: Two Examples of Racial Exclusion}

Immigration policies and practices in Canada occur within a white supremacist, settler-colonial context, where the presence and contributions of racialized migrants have been pervasively excluded. ${ }^{42}$ For example, in the late 1800 and early 1900 Chinese migration was controlled through a head tax, Japanese migration was controlled through a "gentlemen's agreement" between governments, and Indian migrants were completely excluded by imposing a continuous journey provision that demanded that ships sail directly to Canada without layovers. ${ }^{43}$ In the mid-19oos, Caribbean caregivers were excluded from permanent residence on the pretext that their physical constitution could not handle the Canadian cold, and Jewish migrants were limited through a noneis-too-many approach that resulted in a ship full of Jewish refugees, Ms St. Louis, being rerouted back to Europe during the Second World War. ${ }^{44}$

However, with the evolution of immigration and multiculturalism policies, overtly racist criteria for permanent residence were no longer tolerated; instead subtler forms of racialized exclusion were integrated into admission policies for refugee claimants, migrant workers, family class migrants, and permanent residents. ${ }^{45}$ Reforms saw the overhaul of the refugee determination system and reinforcement of "bogus" refugee discourses; increased precarization of temporary foreign workers; increased suspicions of family-class applications, including marriage sponsorship; and changes to the skilled immigration program that limited permanent residence along business models. ${ }^{46}$ As a result, immigration policies have increasingly favoured temporary rather than permanent residents, producing an increased number of pathways that result in precarious status.

From initial attempts to register for primary or secondary school, to applications for admission to post-secondary institutions, the intersection between racialization and immigration status has important impacts on the schooling experiences of migrant youth. In the province of Ontario, the Education Act states that all youth under the age of eighteen (other than tourists or visitors) have access to schooling. ${ }^{47}$ Furthermore, school boards in Toronto, the province's largest city, have adopted access policies. However, admission to primary and secondary institutions remains exclusionary. ${ }^{48}$ Youth and their families are continuously asked by administrators to produce evidence of their immigration status, including their lack of status, though their statuses are frequently misunderstood or challenged. ${ }^{49}$

Once migrant students with precarious status are admitted to schools, they face exclusions related to being an immigrant, their status, and racialization. Immigrant and racialized students are asked to complete Eurocentric curricula, which frequently devalue their knowledge, culture, and histories, affecting their learning outcomes and academic pursuits. ${ }^{50}$ They are streamed into non-academic trades and criminalized through police programs in schools, and they suffer higher rates of push-out. ${ }^{51}$ Parents and communities are often also stigmatized as "deficient" and lacking interest in student success. ${ }^{52}$ The barriers are thereby individualized, with the blame placed on students and their communities rather than the school system that excludes them. Moreover, the lack of secure status affects students' ability to participate fully in non-academic programming, as the lack of health insurance or a social insurance number may limit access to extracurricular activities. ${ }^{53}$ Linking marginalization within the school system to racist and exclusionary immigration policies leads to a "double punishment" for youth with precarious status, which is always underpinned with the violent threat of deportation.

\section{Access to Post-secondary Schooling for Students with Precarious Status in Canada}

Little research has been done on the unique experiences of migrant post-secondary students in Canada (outside of the experiences of international students). ${ }^{54}$ One reason is that access to universities for youth with precarious status has been piecemeal and not very visible. Furthermore, migrants with precarious status are provided with limited guidance or misinformation, ${ }^{55}$ particularly regarding paying international vs. domestic fees, eligibility for residency and work permits, and protection from deportation. The racialized and racist context that many these students also face before and after entering university further augments their precarity. In scholarly research, and from our own community work, we have found that these factors lead some high school students to lose hope and let their grades fall in their senior year of high school once they learn they cannot continue to college or university. ${ }^{56}$

The regulatory framework that organizes entry to postsecondary schooling for students with precarious status 
Table 1: Participant Information

\begin{tabular}{lccccc}
\hline Pseudonym & Age & Gender & $\begin{array}{c}\text { Region of } \\
\text { origin }\end{array}$ & Years in Canada & Status \\
\hline Gabriella & 27 & F & Africa & 4.5 & Refugee claimant \\
Djemba & 26 & M & Africa & 5 & Refugee claimant \\
Joey & 22 & F & Latin America & 5 & Refugee claimant \\
Rayan & 28 & M & Caribbean & 5 & Refugee claimant \\
Laura & 28 & F & Latin America & 6 & Non-status, transitioning to \\
Thomas & 23 & M & Africa & 6 & permanent residence \\
Jefferson & & & & Non-status \\
Sarah Jones & 25 & F & Caribbean & 5 & Non-status \\
Maria & 36 & F & Latin America & 11 & Non-status \\
Zoe & 32 & F & Caribbean & 12 & Non-status \\
Barbara & 22 & $F$ & Latin America & 12 & Non-status \\
Lauren & 22 & Caribbean & 13 & \\
\hline
\end{tabular}

involves the interplay between federal immigration and provincial education policies. Federally, the Immigration and Refugee Protection Act controls migrants' ability to study in Canada by requiring them to apply for study permits, which then legitimizes the charging of international fees. ${ }^{57}$ In Ontario, the Ministry of Advanced Education and Skills Development is responsible for post-secondary institutions and provides funding for each permanent resident/citizen student, which accounts for the difference between domestic and international fees. The ministry will not fund precarious status students, therefore, they are usually charged international fees.

Nonetheless, after a post-secondary institution has received permission to grant degrees, they have freedom to organize their enrolment and other matters independently. While it is encouraging that universities have some power, one concern is that federal policy and provincial funding often make institutions hesitant to explore options vis-à-vis access.

\section{Methods}

Research for this article came as a result of the authors' extended advocacy and work to increase access to postsecondary education for students with precarious status in Toronto, Canada, as well as their involvement in a pilot project at York University, which is the first of its kind in Canada. Approaching this topic from both an academic and community-centred perspective, we draw on research conducted by Villegas with some of the first students to participate in the pilot bridging course. The project took place in the summer and fall of 2017 , after Villegas taught two iterations of the course. Given that participants took the course to transition to York University, research project recruitment did not begin until students were informed they had passed the course, so potential participants did not feel coerced to participate. Informed consent was obtained in a two-step process. First, after reviewing the consent form, participants chose a pseudonym and used that pseudonym to sign it. Second, verbal consent was obtained at the beginning of the audiotaping (or beginning of the interview when the participant opted to not have it audiotaped).

Data include semi-structured interviews with eleven participants and students, as well as assignments including reading reflections, papers, and creative projects. All interviews but one were held in English (the latter was held in Spanish and translated to English by Villegas). Participants can be divided into two groups: those who had graduated from an Ontario high school $(n=4)$ and those who graduated from high school and may have had some post-secondary training in their country of origin $(n=7)$. Participants came from Latin America, the Caribbean, and Africa (countries are not specified, to maintain confidentiality). Their legal status varied from refugee claimants (those waiting for their application for protection to be heard) to no status (those with expired visas or refused refugee claimants), with some of the latter looking for avenues for regularization ${ }^{58}$ through Humanitarian and Compassionate applications (see table 1). ${ }^{59}$ Names used are pseudonyms chosen by participants. Course assignments were linked to participant pseudonyms, and any identifying information was removed. Data were analyzed using open coding, organized according to themes, involving both deductive and inductive analysis. ${ }^{60}$ The 
themes for this article include barriers experienced accessing post-secondary schooling and reflections about how racialization and racism affects residents of Canada.

We also draw directly on Aberman's experience as a service provider within the settlement sector, working closely with a diverse group of newcomer and precarious status youth in Toronto over the past five years. Working in solidarity with the youth as they identified access to education as a primary concern has incited an awareness of the issues faced. Aberman has also been the coordinator of the pilot project at York University, responsible for supporting the development and implementation of administrative changes to admit students with precarious status and for student recruitment and engagement.

\section{Bridging Program}

In January 2017 a pilot program was inaugurated at York University in partnership with the FCJ Refugee Centre, which was made possible through funding from the City of Toronto. ${ }^{61}$ For the first time in Canada, this program sought to specifically support the transition of students with precarious status to university studies. Taking into consideration the differing needs of the potential students, two pathways were created: a direct-entry path for students who were academically and mentally ready to begin an undergraduate degree, and a bridging course for those who felt they needed further preparation or additional support. The bridging course content focused on critical migration studies with the goal of making connections between assignments, texts, and students' lived experiences. Through the course, students were able to conceptualize the systemic power relations that contribute to global migration and inequities between migrants. In addition, the course enabled creation of safe(r) space where students have been able to connect with others facing similar obstacles and identify common challenges. Such spaces are frequently lacking for populations with precarious status. Both entry pathways also included support throughout the application process, major, and course selection.

The course itself was the culmination of community-based strategies to counteract the exclusion of migrant youth with precarious status from post-secondary schooling. For example, a precursor to the bridging program was a communitybased program titled Uprooted University. ${ }^{62}$ Uprooted U was influenced by similar projects in the United States, including Freedom University, in Georgia. ${ }^{63}$ Scholars have identified such projects as working to produce a "transformational solidarity" that prioritizes making connections between students' lived experiences and educational curriculum and working in solidarity across interlocking forms of oppression.$^{64} \mathrm{Simi}$ larly, Muñoz, Espino, and Antrop-Gonzalez, drawing from
Solórzano and Delgado Bernal, use the concept of transformational resistance, which "provide[s] an intentional space in which students are able to question and grapple with issues of oppression in order to work toward developing a more just community." ${ }^{35}$ Such projects purposefully involve conversations about how interlocking forms of oppression affect students' lived experience (i.e., through interlocking forms of punishment). The projects may not fill the gaps to access experienced by students with precarious status, but they can extend student networks and social capital to facilitate enrolment. ${ }^{66}$ Many of the youth who participated in the Uprooted U program were among the first to register for the bridging program at York University.

Recruitment for both pathways, bridging and directentry, was initially contained to trusted networks and word of mouth. While efforts were made to reach as many potential students as possible, the safety of the students was paramount. Migrant Youth with precarious status face layers of criminalization and deportability, which can manifest in uncomfortable or potentially violent interactions with citizens who do not accept their presence, or detention or deportation by immigration officials. All possibilities needed to be considered throughout this pilot program. Despite the limited reach of the recruitment, we were able to fill the bridging courses quite quickly and had several graduating high school students apply for direct entry.

During the interviews with the bridging students, participants identified legal status, limited information, and experiences of racialization as key factors that affected their access to post-secondary schooling. And participants linked their precarious immigration status with the international fee rates imposed on them. Domestic tuition fees are reserved for citizens, permanent residents, and convention refugees, while other students are considered temporary international students who must pay significantly higher fees. These fees make higher education impossible for many students with precarious status. ${ }^{67}$

For instance, Zoe, a non-status woman who graduated from high school in her country of origin, explained feeling "stuck" as a result of the high fees: "I couldn't possibly do university courses because as an international student it's like three times the domestic rate. I don't have that kind of money."

The high fees led some students to "stop out," to pause their education, in order to accumulate money or await a change of status. Djemba, a refugee claimant who graduated from high school in his country of origin, described his own experience of "stopping out," despite being accepted to several post-secondary institutions: "I didn't know that I had to pay that fee, so once the letters came and my fee was like 16,000 per year, I just declined. I just couldn’t do it." Djemba 
realized that he had to put his dreams of higher education on hold until his status changed, as he was unlikely to earn enough money for the fees. Moreover, for Djemba, limited access to resources and networks (social capital) manifested through lack of information, or misinformation, about university access and funding opportunities.

Despite having had some support from her high school teacher, Joey, a refugee claimant who graduated from high school in Canada, also had to "stop out" and forgo acceptance to a local college: "I didn't know fully that I had to pay international student [fees] as refugee claimant ... I didn't find out until ... the deadline to pay the fee for the first year was due. So, I had to drop out of that and the scholarship my teacher had gotten for me."

Finally, Gabriella, a refugee claimant who completed high school in her country of origin, wondered whether there were scholarships for students with precarious status to avoid piecing together precarious, deskilling jobs to pay her fees: “[Now] I'm trying to ask, 'Do you know any scholarships I can apply to?' At least just even have like one course going, and so we don't end up working all those odd jobs, and all those jobs that are not related to our fields all the time. So, we're hoping that we can get scholarships."

While there are very few scholarships or bursaries for students with precarious status, awareness of them might have enabled Gabriella to pursue her studies sooner. The low levels of social capital left these participants without networks to provide them with the information or institutional support they needed, further hindering their efforts to access post-secondary education.

Participants' lived experiences of racialization and racism manifested during interviews. For instance, Thomas Jefferson, who graduated from high school in Canada, reflected on how he might be viewed as a Black male in university: "As long as I don't think about that [the effects of racism]. But at the same time, you have to, 'cause you are a Black man walking around an educational institution. Some people might think you should not be here, you should be in college or even the trades. You know? That's not where I belong so, it's that part of it and general safety." His comment alludes to a "white space" discussed by Clark-Ibáñez, Garcia-Alverdín, and Alva that, although not explicitly a "hyper hate community climate," still excludes racialized students/migrants. ${ }^{68}$ While Thomas Jefferson was discussing the racism he may face in university spaces in the future, these fears could have been based on past experiences.

Participants also discussed the racism they experienced within the education system and the ways that racism leads to dehumanization. ${ }^{69}$ As Barbara, a non-status woman who graduated from high school in Canada, explained, "In high school, during my culinary class, the ... teacher would have a small poster on the wall with the silhouette of a student wearing sagging pants while showing his boxers, as was popular at the time, with a meme-like caption calling them Neanderthals. I'm pretty sure he, and everyone else who disliked the fashion, thought it was witty."

Since the fashion described was worn primarily by racialized males at the time, for Barbara that comparison of her racialized peers to prehistoric, unevolved people was a way to publicly dehumanize them. Barbara went on to explain the connection she saw between the racism she experienced and her precarious position as a refugee claimant. Her explanation reflected the silencing often faced by newcomers with precarious status: "I feel that a reason why immigrants, especially refugees, are hesitant to talk about discrimination in Canada is because they feel that they have to be grateful, and complaining goes against that. They feel like they always have to praise Canada or otherwise they will be faced with criticism, particularly from people who don't want refugees to stay. It's always felt to me like they have to suck up to Canada, regardless of how they really feel."

Maria, a non-status woman who graduated from high school in her country of origin, further articulated a personal sense of dehumanization that emerged through a lack of status: "It always feels like a disadvantage not to have status, is almost like you are a little bit subhuman (if that is even a word). If I say the wrong thing, what consequences can this bring to our family?"

The "subhuman" also connects to the discourses of racialized bodies as less evolved or worthy of progress to which Barbara references through the image of the Neanderthal. As Francisco Villegas argues, "Through the discursive dehumanization of undocumented migrants ... it is possible to facilitate the production of 'illegality' that constructs migrants as disposable. Such dehumanizing practices devalue the worth of migrants' lives and allow for the possibility of collective violence." ${ }^{70}$ In her description, Barbara explained that this violence can lead to the censoring of migrants' critiques, particularly when they do not align with the gratitude immigrants are expected to project towards to the nation, even in the face of ongoing racism.

Interviews ended by asking participants whether the bridging program should continue. Each participant responded with a resounding yes, but for different reasons. For instance, Zoe discussed the course's role as a bridge: "Specially if somebody has been away from schooling for awhile, it's a very effective way to ease back into it, as opposed to just jumping in.... It's actually overwhelming. Especially if you have no experience with the Canadian schooling system."

Other participants identified the program's individual value, as well as the community need. Gabriella mentioned, "I believe that it gives a lot of hope for those that are losing 
hope." Sarah Jones, a non-status woman who completed high school in her country of origin, stated, "Because it did good for me and the other people who I know right now, they're saying, 'When you hear about stuff like that again, you should let me know." Finally, Barbara stated, "There's a lot of people in my situation and there will be more. And like me, it gave me a sense of purpose. I wasn't just being a slob. And it's very helpful that there's a chance to be able to become a student. It's not only about feeling a sense of purpose, but it's actually you could get a degree, it's beneficial for a person's job."

These responses articulate a transformational solidarity/ resistance by identifying the importance of others participating in the program and the fact that they sought further education to contribute to their families and communities. Furthermore, the bridging program was designed to support students as they started their university studies but did not guarantee an open door to university. Nevertheless, being in the program was an act of resistance itself, to the dehumanization and double punishment that participants had experienced. The course also allowed for critical discussions (and contradictions) about race, immigration status, and understanding of immigrant deservingness, broadening and contextualizing students' theorizations of their experiences. Finally, students' participation in the program increased their access to networks, resources, and the possibility of entering university, even if not immediately, given the fact that enrolment fees can be prohibitive. However, students articulated the desire to engage in a transformational resistance to the university's oppressive structures through their presence and actions, once they enrolled.

\section{Conclusion}

There is no indication that the immigration policies that favour precarious temporary migrants over permanent residents will change any time soon, therefore the "double punishment" faced by students with precarious status is an ongoing inequity. The racialized pathways to precarious status continue to exclude migrants in ever-evolving ways that are designed to fall within Canada's multicultural fabrication. Within this context, for migrant youth, schools become a necessary site of participation, yet one that relies on a racialized, status-dependant reception. In this article we examined the racialized system of immigration and schooling institutions that produce social exclusion for migrants with precarious status in Canada. We argued that the ways racism intersects with the immigration system, as well as equitable access to education, leads to a "double punishment" for precarious status students.

This punishment intensifies at the entrance to postsecondary education. While migrant youth with precarious status had been all but bared from accessing college or university in Ontario, a new initiative at York University is addressing this exclusion through a bridging program and a process for admission to undergraduate degrees. Students who have seized these opportunities have described the life-changing possibilities for which they are now striving. While there are still many challenges to overcome, particularly exclusions related to racialized and immigration status within education systems, lessons can be learned from the United States, where there has been greater access to postsecondary education for students with precarious status. These lessons can apply to Canadian projects, as they have with the one discussed in this article. Universities and colleges across Canada can also adopt inclusionary practices to counter their presence as racialized and immigration status centred sites, to reduce the barriers that prevent certain students from following their dreams.

\section{Notes}

1 We would like to thank the Bridging students for participating in the course and learning with us through this process, and Yvette Munro for her commitment and vision in making the project a reality. We would also like to thank the anonymous reviewers for their generous comments.

2 Himani Bannerji, The Dark Side of the Nation: Essays on Multiculturalism, Nationalism and Gender (Toronto: Canadian Scholars' Press, 2000); Nandita Sharma, "Canadian Multiculturalism and Its Nationalisms," in Home and Native Land: Unsettling Multiculturalism: Lands, Labours, Bodies, edited by May Chazan Lisa Helps, Anna Stanley, and Sonali Thakkar (Toronto: Between the Lines Publishers, 2011).

3 Peter S. Li, "The Racial Subtext in Canada's Immigration Discourse," Journal of International Migration and Integration 2, no. 1 (2001): 77-97; Sunera Thobani, Exalted Subjects: Studies in the Making of Race and Nation in Canada (Toronto: University of Toronto Press, 2007); Harsha Walia, Undoing Border Imperialism, Anarchist Interventions (Oakland, CA: AK, 2013).

4 Luin Goldring, Carolina Berinstein, and Judith Bernhard, "Institutionalizing Precarious Migratory Status in Canada," Citizenship Studies 13, no. 3 (2009): 239-65; Luin Goldring and Patricia Landolt, eds., Producing and Negotiating NonCitizenship: Precarious Legal Status in Canada (Toronto: University of Toronto Press, 2013).

5 Michael A. Olivas, No Undocumented Child Left Behind: Plyler v. Doe and the Education of Undocumented Schoolchildren (New York: NYU Press, 2012).

6 Francisco Villegas, “'Access without Fear!': Reconceptualizing 'Access' to Schooling for Undocumented Students in Toronto," Critical Sociology 43, no. 7-8 (2016): 1178-95.

7 Carl James and Tana Turner, "Towards Race Equity in Education: The Schooling of Black Students in the Greater 
Toronto Area" (Toronto: York University 2017); Sara Schroeter and Carl James, "We're Here Because We're Black': The Schooling Experiences of French-Speaking African-Canadian Students with Refugee Backgrounds," Race Ethnicity and Education 18, no. 1 (2015): 20-39; FCJ Youth Network, Uprooted Education: 2015-2016 Ontario Report (Toronto: FCJ Refugee Centre, 2016).

8 Mae M. Ngai, "A Call for Sanctuary," Dissent 64, no. 1 (2017): 16-19; National Immigration Law Center, "Basic Facts about In-State Tuition for Undocumented Immigrant Students," last updated June 1, 2018, https://www.nilc.org/ issues/education/basic-facts-instate/.

9 Paloma E. Villegas, "Bridging Borders: Teaching a Bridging Course with Precarious Status Students Transitioning to the University," in Critical Schooling: Transformative Theory and Practice, edited by Francisco J. Villegas and Janelle Brady, 245-68 (New York: Springer, 2019); Anthony Reinhart, "Good Enough for a Federal Scholarship," Globe and Mail, March 6, 2008, https://www.theglobeandmail.com/news/national/good-enough-for-a-federalscholarship/article18447155/; Ryan Hayes, "Neoliberal Citizenship: The Case of International and Non-Status Students in Canada," in Documenting the Undocumented: Redefining Refugee Status, Center for Refugee Studies 2009 Annual Conference Proceedings, edited by Veronica P. Fynn, 101-9 (Boca Raton, FL: Universal Publishers, 2009); Lesley Ciarula Taylor, "Immigrant Crackdown Derails Studies," Toronto Star, September 22, 2008, https://www .thestar.com/news/gta/2008/o9/22/immigrant_crackdown_ derails_studies.html; CTV News, "U of T Students Fight Deportation Order," https://toronto.ctvnews.ca/u-of-tstudents-fight-deportation-order-1.368688.

10 Rogelio Sáenz and Karen Manges Douglas, "A Call for the Racialization of Immigration Studies: On the Transition of Ethnic Immigrants to Racialized Immigrants," Sociology of Race and Ethnicity 1, no. 1 (2015): 166-180.

11 Abdelmalek Sayad, The Suffering of the Immigrant (Cambridge, uk: Polity, 2004).

12 Gloria Ladson-Billings, "Just What Is Critical Race Theory and What's It Doing in a Nice Field Like Education," in The RoutledgeFalmer Reader in Multicultural Education, 49-68 (Oxon: RoutledgeFalmer, 2004).

13 Richard Delgado and Jean Stefancic, Critical Race Theory: An Introduction (New York: NYU Press, 2017).

14 Kimberle W. Crenshaw, "Demarginalizing the Intersection of Race and Sex: A Black Feminist Critique of Antidiscrimination Doctrine," University of Chicago Legal Forum 1989, no. 1 (1989): 139-67.

15 Ladson-Billings, "Just What Is Critical Race Theory."

16 Juan Herrera, "Racialized Illegality: The Regulation of Informal Labor and Space," Latino Studies 14, no. 3 (2016): 320-43; San Juanita García, "Racializing 'Illegality': An Intersectional Approach to Understanding How MexicanOrigin Women Navigate an Anti-Immigrant Climate," Sociology of Race and Ethnicity 3, no. 4 (2017): 474-90.
17 Nicholas De Genova, "The Legal Production of Mexican/ Migrant 'Illegality," Latino Studies 2, no. 2 (2004): 160-85.

18 García, "Racializing 'Illegality”, 474.

19 Nicholas De Genova, "Migrant 'Illegality' and Deportability in Everyday Life," Annual Review of Anthropology 31 (2002): 419-47.

20 Roberto G. Gonzales, Lives in Limbo: Undocumented and Coming of Age in America (Oakland, CA: University of California Press, 2016); Veronica Terriquez, "Dreams Delayed: Barriers to Degree Completion among Undocumented Community College Students," Journal of Ethnic and Migration Studies 41, no. 8 (2015): 1302-23.

21 Eve Geddie, “Undocumented Migrants' Right to Health and Education in Europe: Protection Needs vs. Immigration Control," in European Social Watch Report, Migrants in Europe as Development Actors: Between Hope and Vulnerability, 29-31 (Brussels: European Social Watch, 2009); Kamena Dorling, "Growing Up in a Hostile Environment: The Rights of Undocumented Migrant Children in the UK" (Colchester: Migrant Children's Project, 2013).

22 De Genova, "Migrant 'Illegality"; Leisy J. Abrego, “I Can't Go to College Because I Don't Have Papers': Incorporation Patterns of Latino Undocumented Youth," Latino Studies 4, no. 3 (2006): 212-31; Gonzales, Lives in Limbo; Michael A. Olivas, "IIrIRA, the Dream Act, and Undocumented College Student Residency," Journal of College and University Law 30, no. 2 (2004): 435-64; Marisol Clark-Ibáñez, Fredi Garcia-Alverdín, and Gricelda Alva, "A Passport to Education: Undocumented Latino University Students Navigating Their Invisible Status," in International Handbook of Migration, Minorities and Education, edited by Zvi Bekerman and Thomas Geisen, 497-513 (Dordrecht: Springer, 2012); Terriquez, "Dreams Delayed."

23 Laura E. Enriquez, "A 'Master Status' or the 'Final Straw'? Assessing the Role of Immigration Status in Latino Undocumented Youths' Pathways out of School," Journal of Ethnic and Migration Studies 43, no. 9 (2017): 1526-43; Breanne J. Palmer, "The Crossroads: Being Black, Immigrant, and Undocumented in the Era of \#Blacklivesmatter," Georgetown Journal of Law and Modern Critical Race Perspectives 9, no. 2 (2017): 99-121; Loan Thi Dao, "Out and Asian: How Undocu/DAcAmented Asian Americans and Pacific Islander Youth Navigate Dual Liminality in the Immigrant Rights Movement," Societies 7, no. 3 (2017): 17-32.

24 Gonzales, Lives in Limbo; Roberto G. Gonzales and Leo R. Chavez, "Awakening to a Nightmare': Abjectivity and Illegality in the Lives of Undocumented 1.5-Generation Latino Immigrants in the United States," Current Anthropology 53, no. 3 (2012): 255-81; Lindsay Perez Huber, "Using Latina/o Critical Race Theory (Latcrit) and Racist Nativism to Explore Intersectionality in the Educational Experiences of Undocumented Chicana College Students," Educational Foundations 24, no. 1-2 (2010): 77-96; Terriquez, "Dreams Delayed."

25 Bridget Anderson, "Migration, Immigration Controls and the Fashioning of Precarious Workers," Work, Employment 
\& Society 24, no. 2 (2010): 300-17; Judy Fudge, "Precarious Migrant Status and Precarious Employment: The Paradox of International Rights for Migrant Workers," Comparative Labor Law \& Policy Journal 34, no. 1 (2012): 95-131; Cheryl Teelucksingh and Grace-Edward Galabuzi, Working Precariously: The Impact of Race and Immigrants Status on Employment Opportunities and Outcomes in Canada (Toronto: Canadian Race Relations Foundation and Centre for Social Justice, 2005).

26 Pierre Bourdieu, "The Forms of Capital," in Handbook of Theory and Research for the Sociology of Education, edited by J.G. Richardson, 241-58 (New York: Greenwood, 1985).

27 Laura W. Perna and Martin A. Titus, “The Relationship between Parental Involvement as Social Capital and College Enrollment: An Examination of Racial/Ethnic Group Differences," Journal of Higher Education 76, no. 5 (2005): 485-518.

28 Clark-Ibáñez, Garcia-Alverdín, and Alva, "Passport to Education"; Laura E. Enriquez, "Because We Feel the Pressure and We Also Feel the Support': Examining the Educational Success of Undocumented Immigrant Latina/o Students," Harvard Educational Review 81, no. 3 (2011): 476-500; Enriquez, "A 'Master Status' or the 'Final Straw'?”; Michael J. Trivette and David J. English, "Finding Freedom: Facilitating Postsecondary Pathways for Undocumented Students," Educational Policy 31, no. 6 (2017): 858-94.

29 Enriquez, "Because We Feel the Pressure"; Julian Jefferies and Dafney Dabach, "Breaking the Silence: Facing Undocumented Issues in Teacher Practice," Association of Mexican American Educators Journal 8, no. 1 (2015): 83-93.

30 Enriquez, "Because We Feel the Pressure," 477; Dao, "Out and Asian."

31 Gender-neutral term to refer to persons of Latin American origins.

32 Palmer, "Crossroads," 114.

33 Dao, "Out and Asian."

34 Terriquez, "Dreams Delayed"; George J. Sefa Dei, Reconstructing "Dropout": A Critical Ethnography of the Dynamics of Black Students' Disengagement from School (Toronto: University of Toronto Press, 1997).

35 Jeffrey S. Passel, "Unauthorized Migrants: Numbers and Characteristics." Background briefing prepared for Task Force on Immigration and America's Future (Washington, DC: Pew Hispanic Center, 2005).

36 Abrego, "I Can’t Go to College”; Clark-Ibáñez, GarciaAlverdín, and Alva, "Passport to Education."

37 Teri Jan Albrecht, "Challenges and Service Needs of Undocumented Mexican Undergraduate Students: Students' Voices and Administrators' Perspectives" (University of Texas at Austin, 2007); Yolanda T. Rangel, "College Immigrant Students: How Undocumented Female Mexican Immigrant Students Transition into Higher Education" (UCLA, 2001).

38 Perez Huber, "Using Latina/o Critical Race Theory"; Shaun R. Harper and Sylvia Hurtado, "Nine Themes in Campus
Racial Climates and Implications for Institutional Transformation," New Directions for Student Services 120 (2007): 77-96.

39 Clark-Ibáñez, Garcia-Alverdín, and Alva, "Passport to Education," 504.

40 Francisco Villegas, "Strategic In/Visibility and Undocumented Migrants," in Fanon \& Education: Thinking Through Pedagogical Possibilities, edited by George J. Sefa Dei and Marlon Simmons, 147-70 (New York: Peter Lang, 2010); Claudia A. Anguiano and Lourdes G. Nájera, "Paradox of Performing Exceptionalism: Complicating the Deserving/ Underserving Binary of Undocumented Youth Attending Elite Institutions," Association of Mexican American Educators Journal 9, no. 2 (2015): 45-56.

41 Terriquez, "Dreams Delayed."

42 Sherene Razack, Race, Space, and the Law: Unmapping a White Settler Society (Toronto: Between the Lines, 2002); Enakshi Dua, "Canadian Anti-Racist Feminist Thought: Scratching the Surface of Racism," in Scratching the Surface: Canadian Anti-Racist Feminist Thought, edited by Enakshi Dua and Angela Robertson (Toronto: Women's Press, 1999).

43 Enakshi Dua, "Exclusion through Inclusion: Female Asian Migration in the Making of Canada as a White Settler Nation," Gender Place and Culture 14, no. 4 (2007): 44566; Alan Simmons, Immigration and Canada: Global and Transnational Perspectives (Toronto: Canadian Scholars' Press, 2010).

44 Canadian Council for Refugees, "A Hundred Years of Immigration to Canada 1900-1999," 2000, http://ccrweb .ca/en/hundred-years-immigration-canada-1900-1999.

$45 \mathrm{Li}$, "Racial Subtext in Canada's Immigration Discourse"; Vic Satzewich and Nikolaos Liodakis, "Race" and Ethnicity in Canada: A Critical Introduction, 3rd ed. (Toronto: Oxford University Press, 2013); Loyd Wong and Shibao Guo, "Canadian Ethnic Studies in the Changing Context of Immigration: Looking Back, Looking Forward," Canadian Ethnic Studies 50, no. 1 (2018): 1-9.

46 Naomi Alboim and Karen Cohl, "Shaping the Future: Canada's Rapidly Changing Immigration Policies," Maytree, 2012, https://maytree.com/wp-content/uploads/shapingthe-future.pdf.

47 Education Act, RSO 1990, c E.2, https://www.ontario.ca/ laws/statute/9oeo2.

48 FCJ Youth Network, Uprooted Education; Tanya Aberman and Philip Ackerman, "Isn't the Right to an Education a Human Right?," in Youth as/in Crisis, edited by Sara Carpenter and Shahrzad Mojab, 127-44 (Rotterdam: SensePublishers, 2017).

49 FCJ Youth Network, Uprooted Education.

50 Aberman and Ackerman, "Isn't the Right to an Education a Human Right?"; Yan Guo, "Diversity in Public Education: Acknowledging Immigrant Parent Knowledge," Canadian Journal of Education 35, no. 2 (2012): 120-40.

51 Dei, Reconstructing "Dropout"; Grace Edward Galabuzi, "Race and the Streaming of Ontario's Children and Youth," 
Our Schools Ourselves 23, no. 2 (2014: 185-226; James and Turner, "Towards Race Equity in Education"; FCJ Youth Network, Uprooted Education; Schroeter and James, "We're Here Because We're Black"; Paul Ansief, Learning and Sociological Profiles of Canadian High School Student: An Overview of 15- to 18-Year-Olds and Educational Policy Implications for Dropouts, Exceptional Students, Employed Students, Immigrant Students, and Native Youth in Ontario (New York: Edwin Mellen, 1994); Samuel Noh, Morton Beiser, Violet Kaspar, Feng Hou, and Joanna Rummens, "Perceived Racial Discrimination, Depression and Coping: A Study of South East Asian Refugees in Canada," Journal of Health and Social Behavior 40 (1999): 193-207; Jacqueline Oxman-Martinez, Anneke J. Rummens, Jacques Moreau, Ye R. Choi, Morton Beiser, Linda Olgilvie, and Robert Armstrong, "Perceived Ethnic Discrimination and Social Exclusion: Newcomer Immigrant Children in Canada," American Journal of Orthopsychiatry 82, no. 3 (2012): 376-88; Yogendra B. Shakya, Sepali Guruge, Michaela Hynie, Arzo Akbari, Mohamed Malik, Sheila Htoo Azza Khogali, Stella A. Mona, Rabea Murtaza, and Sarah Alley, "Aspirations for Higher Education among Newcomer Refugee Youth in Toronto: Expectations, Challenges, and Strategies," Refuge 27, no. 2 (2012): 65-78.

52 Francisco Villegas, "Prescribed Lack: The Prevalence and Dangers of Deficiency Theories to Explain the Latina/o Schooling Experience in Toronto," Latin American Encounters 2 (2014): 40-50.

53 FCJ Youth Network, Uprooted Education.

54 Faria Kamal and Kyle D. Killian, "Invisible Lives and Hidden Realities of Undocumented Youth," Refuge 31, no. 2 (2015): 63-74; Julie Young, “This Is My Life: Youth Negotiating Legality and Belonging in Toronto," in Producing and Negotiating Non-Citizenship: Precarious Legal Status in Canada, edited by Luin Goldring and Patricia Landolt, 99-117 (Toronto: University of Toronto Press, 2013); Aberman and Ackerman, "Isn't the Right to an Education a Human Right?"

55 Jaswant Kaur Bajwa, Sidonia Couto, Sean Kidd, Roula Markoulakis, Mulugeta Abai, and Kwame McKenzie, "Refugees, Higher Education, and Informational Barriers," Refuge 33, no. 2 (2017): 56-65.

56 FCJ Youth Network, Uprooted Education; Aberman and Ackerman, "Isn't the Right to an Education a Human Right?"

57 There are some exceptions, but those students are still required to have authorized visitor status. See Immigration and Refugee Protection Act, sC 2001, c 27, http://canlii .ca/t/53bgk.

58 Not everyone applied for regularization, because the process of applying is onerous and expensive, and if it is unsuccessful, it plugs migrants into a surveillance web that further illegalizes them. See Paloma E. Villegas, "Fishing for Precarious Status Migrants: Surveillant Assemblages of Migrant Illegalization in Toronto, Canada," Journal of Law and Society 42, no. 2 (2015): 230-52.
59 Application measures establishment in Canada related to occupation and community engagement, and does not protect from deportation; see Immigration Refugees and Citizenship Canada, "Humanitarian and Compassionate Assesment: Establishment in Canada," www.cic.gc.ca/english/ resources/tools/perm/hc/processing/establishment.asp.

60 J.M. Corbin and A. Strauss, "Grounded Theory Research: Procedures, Canons, and Evaluative Criteria," Qualitative Sociology 13, no. 1 (1990): 3-21.

61 Mary Weims, "York First Canadian University to Give 'Dreamers' a Chance at a Degree," свс News, January 15, 2018. http://www.cbc.ca/news/canada/toronto/ canadian-dreamers-york-university-1.4488252.

62 Tanya Aberman, Francisco Villegas, and Paloma E. Villegas, eds., Seeds of Hope: Creating a Future in the Shadows (Toronto: FCJ Refugee Centre, 2016); Aberman and Ackerman, "Isn't the Right to an Education a Human Right?"

63 Laura E. Soltis, "From Freedom Schools to Freedom University: Liberatory Education, Interracial and Intergenerational Dialogue, and the Undocumented Student Movement in the Us South," Souls 17, no. 1-2 (2015): 20-53; Susana Muñoz, Michelle M. Espino, and Rene Antrop-Gonzalez, "Creating Counter-Spaces of Resistance and Sanctuaries of Learning and Teaching: An Analysis of Freedom University," Teachers College Record 116, no. 7 (2014): 1-32; Trivette and English, "Finding Freedom."

64 Palmer, "Crossroads," 116.

65 Muñoz, Espino, and Antrop-Gonzalez, "Creating CounterSpaces," 20; Daniel G. Solórzano and Dolores Delgado Bernal, "Examining Transformational Resistance through a Critical Race and Latcrit Theory Framework: Chicana and Chicano Students in an Urban Context," Urban Education 36, no. 3 (2001): 308-42.

66 Trivette and English, "Finding Freedom."

67 Aberman and Ackerman, "Isn't the Right to an Education a Human Right?"

68 Clark-Ibáñez, Garcia-Alverdín, and Alva, "Passport to Education."

69 Villegas, "Strategic In/Visibility and Undocumented Migrants"; Frantz Fanon, Black Skin, White Masks (New York: Grove, 1967).

70 Villegas, "Strategic In/Visibility and Undocumented Migrants," 156.

Paloma E. Villegas is an assistant professor at California State University, San Bernardino. The author may be contacted at paloma.villegas@csusb.edu.

Tanya Aberman is the coordinator for the access program for students with precarious immigration status at York University. She also recently completed her PhD in women's studies at York University. She can be reached at taberman@yorku.ca. 